\title{
MIR15A Gene
}

National Cancer Institute

\section{Source}

National Cancer Institute. MIR15A Gene. NCI Thesaurus. Code C81884.

This gene is involved in the regulation of gene expression and plays a potential tumor suppressor role in prostate carcinomas, various leukemias, pituitary adenoma, polycystic kidney disease and polycystic liver disease. 